\title{
THE EXAMINATION OF ESAT-6, CFP-10, MPT-64 ANTIGENS OF Mycobacterium tuberculosis IN URINE OF PEDIATRIC TUBERCULOSIS PATIENT WITH IMMUNOCHROMATOGRAPHY TO SUPPORT THE DIAGNOSIS
}

\author{
Anita Budiarti' ${ }^{\text {, Jusak Nugraha }}{ }^{2}$, Agung Dwi Wahyu Widodo ${ }^{3}$ \\ ${ }^{1}$ Immunology Program, ${ }^{2}$ Department of Clinical Pathology, ${ }^{3}$ Department of Microbiology, Faculty of Medicine, \\ Universitas Airlangga, Dr. Soetomo Hospital, Surabaya, Indonesia
}

\section{ABSTRACT}

Tuberculosis in children is often a systemic complication because of their imperfect cellular immune system. ESAT-6, CFP-10, and MPT-64 are small molecular dominant antigens secreted by Mtb into the blood and filtered by the kidneys into urine. The high proportion of children with TB cases according to the Ministry of Health of the Republic of Indonesia in 2013 was $7.9 \%-12 \%$. Diagnis is difficult to establish with sputum and blood samples. Therefore, it is necessary to support the diagnosis using urine samples with ICT rapid test. The purpose of this study was to determine the examination of Mtb ESAT-6, CFP-10, and MPT-64 antigens in the urine of pediatric TB patients with ICT to support the diagnosis. The method used was analytic observation with case control design. The results of the study showed that 32 of the urine of children with TB who were examined with ICT, 22 showed ESAT-6, CFP-10, and MPT-64 positive and 10 negative. Whereas, from 32 urine of healthy children, 25 were negative and 7 were positive. Analysis results showed $95 \%$ confidence $(C I), p=0.0002(p<0.05), 78 \%$ specificity and $68.8 \%$ sensitivity compared to TB diagnosis from pediatricians. As a conclusion, Mtb ESAT-6, CFP-10, and MPT-64 antigens can be examined in the urine of pediatric TB patients with ICT to support the diagnosis.

Keywords: Antigen; Mtb; urine; pediatric patients; ICT

\section{ABSTRAK}

Tuberkulosis anak sering menjadi komplikasi sistemik karena sistem imun selulernya yang belum sempurna. ESAT-6, CFP-10, dan MPT-64 adalah antigen dominan dengan berat molekul kecil yang disekresikan oleh Mtb ke darah dan difiltrasi oleh ginjal menjadi urine. Proporsi kasus TB anak yang tinggi menurut Kemenkes RI 2013 adalah 7,9\%-12\%. Diagnosis sulit dilakukan dengan sampel dahak dan darah. Oleh karena itu, sampel urin dengan rapid test ICT perlu dilakukan untuk menunjang diagnosis. Tujuan penelitian ini adalah untuk mengetahui pemeriksaan antigen Mtb ESAT-6, CFP-10, dan MPT-64 pada urin pasien TB anak dengan ICT untuk menunjang diagnosis. Metode penelitian adalah observasi analitik dengan rancangan penelitian case control. Hasil penelitian pada 32 urine pasien TB anak yang diperiksa dengan ICT menunjukkan 22 positif ESAT-6, CFP-10, dan MPT-64 dan 10 negatif. Sedangkan, 32 urin anak sehat menunjukkan 25 negatif dan 7 positif. Hasil analisis menunjukkan tingkat kepercayaan (CI) 95\%, $p=$ 0,0002 ( $p<0.05$ ), spesifisitas $78 \%$ dan sensitifitas $68,8 \%$ dibandingkan dengan diagnosis TB dari dokter anak. Sebagai simpulan, antigen Mtb ESAT-6, CFP-10, dan MPT-64 dapat diperiksa pada urin pasien TB anak dengan ICT untuk menunjang diagnosis

Kata kunci: Antigen; Mtb; urin; pasien anak; ICT

Correspondence: Anita Budiarti, Perum TAS 3 Blok P5 No 15 Tulangan, Sidoarjo, East Java, Indonesia. Phone: +6281333279397. E-mail: anitabudiarti38@gmail.com

\footnotetext{
pISSN:2355-8393 • eISSN: 2599-056x • doi: http://dx.doi.org/10.20473/fmi.v54i3.10014

- Fol Med Indones. 2018;54:195-199 • Received 2 Nov 2017 • Accepted 17 May 2018

- Open access under CC-BY-NC-SA license • Available at https://e-journal.unair.ac.id/FMI/
}

\section{INTRODUCTION}

Tuberculosis (TB) is an infectious disease. It is caused by the Mycobacterium tuberculosis (Mtb). Tuberculosis can enter the body along a grain of dust or splashing of phlegm (droplets) that spread during coughing or sneezing (Wahyuningsih 2014). Mtb is an obligate aerobe, which requires oxygen to grow. This describes why most frequent TB predilection is in the top lobe of the lung tissue where high oxygen level is found (Raviglione et al 2012).

Pediatric TB is different from that of adults. Children have immature cellular immunity. Therefore, pediatric TB often occurs as systemic complications (Ministry of Health of Republic of Indonesia 2013). Early Secretory Antigen Tuberculosis 6 (ESAT-6), Culture Filtrate Protein 10 (CFP-10), Mycobacterium Protein Tubercul- 
osis 64 (MPT-64) antigens are specific antigens of Mtb (Arora et al 2015). The antigens are secreted actively by Mtb from infected alveolar macrophages. The antigens are circulated in the blood and then processed in the kidney. In the kidney, the blood is filtered by the glomerolus, reabsorbed by the proximal tubule, and augmented by the distal tubule (Yusa \& Maniam 2016).

ESAT-6, CFP-10, and MPT-64 are region of difference (RD) 1,2 (Kleinnijenhuis et al 2011). The antigens have small molecular weights. ESAT- 6 has $6 \mathrm{kDa}$, CFP-10 has $10 \mathrm{kDa}$, and MPT-64 has a molecular weight that varies from 22.3 to $28 \mathrm{kDa}$. Thus, they can be excreted along with the urine, since molecules weighing less than $67 \mathrm{kDa}$ can escape freely from glomerolus filtration and most of the proximal tubules reabsorbtion until become urine excretion (Tuuminen 2012).

The proportion of pediatric TB cases in Indonesia is $7.9 \%-12 \%$ (Gustiani et al 2014) because of late diagnosis. The diagnosis of pediatric TB is more difficult than that in adult. This is caused by several reasons, among others, non-specific clinical symptoms, difficult sputum sampling, paucibacillary, inadequate laboratory examination, and Mtb culture that takes relatively longer time (Noussair et al 2009).

Therefore, it is important to conduct study on the examination of ESAT-6, CFP-10, and MPT-64 antigens of Mtb in urine of pediatric TB patient with immunochromatography to support the diagnosis. The immunochromatographic method is a rapid test and has high validity (Gustiani et al 2014). In another study, it was concluded that TBAg rapid test can be used as new diagnostic method in pulmonary TB, especially in inadequate health services (Sari 2011). There are several studies on TBAg rapid test, but the use of urine samples in pediatric TB patient has never been performed before.

\section{MATERIALS AND METHODS}

This study used case control study design (Notoatmodjo 2012). Case groups used urine samples from pediatric patients who had been diagnosed with TB disease by pediatricians at Dr. Soetomo Hospital, Surabaya, from January to August 2017. The diagnosis became the inclusion criterion. Whereas, the control group used healthy urine sample that had never been in contact with adult TB, normal thorax, and negative tuberculin skin test. The samples were 32 urine samples of pediatric TB patients and 32 urine samples of healthy children.

Urine was centrifuged at $10.000 \mathrm{rpm}$ for 20 minutes to create concentrated urine, since concentrated urine avoids confounding factors and is capable to obtain urine analysis up to the smallest molecular weight (Thomas et al 2010). Besides, concentrated urines could be examined by immunochromatography (ICT) to get positive or negative result of Mtb's ESAT-6, CFP-10, MPT-64 antigens.

ICT is a method of detection of antigens or antibodies specific to a sample that utilizes the principle of immunological reaction, that is the presence of antibodyantigen bond. The urine concentrate was entered at the sample site on the chromatographic cassette, so that it migrated to the capillary membrane to the other end of the ICT cassette. When migrating, the sample passed a T-line containing specific antibodies. If the samples contained ESAT-6, CFP-10, MPT-64 antigens, the antigen would bind to specific antibodies on the $\mathrm{T}$-line and the remainder would pass on and attach to line $\mathrm{C}$ along with other antibodies, appeared pink in the $\mathrm{T}$ and $\mathrm{C}$ lines, so it was concluded as positive. However, if there were no ESAT-6, CFP-10, MPT-64 antigens in the sample, only the bonds existed between other antigens present in the sample with recombinant proteins/ antibodies on line $\mathrm{C}$, which appeared pink in line $\mathrm{C}$ only, so it was concluded as negative.

ICT examination was conducted at the Diagnostic Center Building, Dr Soetomo Hospital, Surabaya. Furthermore, the results of the examination were analyzed using chi-square Wilson Brown test, so that the $\mathrm{p}$ value, and specificity and sensitivity percentages could be found.

\section{RESULTS}

The results of pediatric TB urine examination with ICT showed mostly positive antigen containing ESAT-6, CFP-10, and MPT-64. Twenty-two from 32 samples of pediatric TB urine were positive with sensitivity of $68.8 \%$, while the result of urine examination of healthy children with ICT showed more negative than positive. From 32 samples, 25 were negative with the specificity of $78 \%$. These results can be seen in Table 1 .

This study showed that the positive antigens mostly come from the pediatric pulmonary TB patient (Table 2). From 14 urine samples of pediatric pulmonary TB patients, all of them were positive. This indicated that the examination of ESAT-6, CFP-10, and MPT-64 antigen of Mtb could use urine sample by means of ICT with the sensitivity of $100 \%$ for the pediatric pulmonary patients. In pediatric extrapulmonary TB patients, positive findings were found because of the treatment with anti tuberculosis drug for less than 1 month (Table 3 ), while the negative ones were because of the treat- 
ment for more than 1 month. Eight positive samples from 18 had the sensitivity of $44 \%$. The data can be seen in Table 4. This underlines that ESAT-6, CFP-10, and MPT-64 antigens of Mtb can be examined using urine samples of pediatric TB patients with ICT to support diagnosis, but its use for pediatric pulmonary TB patients provided the best results.

\section{DISCUSSION}

In this study, urine samples were used because it had some advantages. Urine is easier to obtain than serum and sputum, can be obtained in large volumes in a noninvasive manner, and no high risk for laboratory workers compared with serum and sputum. In addition, urine is also increasingly being studied as an easy-to-use clinical samples for the identification of mycobacteria for tuberculosis diagnosis.

The study showed positive results than negative ones. This is consistent with results in several studies which found that ESAT-6, CFP-10, and MPT-64 antigens are secreted actively from infected alveolar macrophages (Bekmuryazeva et al 2013, Smith 2003). The ESAT-6 antigen also has the ability to form pores in erythrocyte membranes and macrophages, so that ESAT-6, CFP-10 and MPT-64 antigen secretion may occur even if mycobacteria are still in the macrophages or in granulomas at the anatomical site of the affected organ. Increased levels of ESAT-6, CFP-10, and MPT-64 antigens facilitate the entry of antigens into the systemic circulation (Krishnan et al 2010).

Table 1. Result of urine examination with ICT in TB and healthy children

\begin{tabular}{lccc}
\hline \multicolumn{1}{c}{ Diagnosis } & Pediatric patient of & Healthy children & Total \\
\hline Antigen + & TB & 7 & 29 \\
antigen - & 22 & 25 & 35 \\
Total & 10 & 32 & 64 \\
\hline
\end{tabular}

Table 2. Result of urine examination with ICT in pulmonary TB and extra pulmonary TB

\begin{tabular}{lccc}
\hline Diagnostic & $\begin{array}{c}\text { Pediatric patient } \\
\text { of pulmonary TB }\end{array}$ & $\begin{array}{c}\text { Pediatric patient of } \\
\text { extrapulmonary TB }\end{array}$ & Total \\
\hline Antigen + & 14 & 8 & 22 \\
Antigen - & 0 & 10 & 10 \\
Total & 14 & 18 & 32 \\
\hline
\end{tabular}

Table 3. ICT results and the length of anti-tuberculosis drug treatment in pediatric extrapulmonary TB patients

\begin{tabular}{lccc}
\hline \multirow{2}{*}{ ICT results } & \multicolumn{2}{c}{ Time of anti tuberculosis drug treatment } & \multirow{2}{*}{ Total } \\
\cline { 2 - 3 } & Less than 1 month & More than 1 month & \\
\hline Antigen + & 8 & 0 & 8 \\
Antigen - & 0 & 10 & 10 \\
Total & 8 & 10 & 18 \\
\hline
\end{tabular}

Table 4. Analysis results

\begin{tabular}{lcc}
\hline P value and statistical significance & Information & Information \\
\hline Test & Chi-square & \\
P value & 0.0002 & \\
One- or two-sided & Two sided & \\
Statistically significant $(\mathrm{p}<0.05)$ & Yes & $95 \% \mathrm{CI}$ \\
Effect size & Value & 0.5143 to 0.8205 \\
Sensitivity & 0.6875 & 0.6125 to 0.8898 \\
Spesivicity & 0.7813 & \\
Sentitivity, specivicity & Wilson-Brown & \\
\hline
\end{tabular}


The results of this study found that ESAT- 6 antigen was a protein with a molecular weight of $6 \mathrm{kDa}$, CFP-10 antigen was a protein with a molecular weight of 10 $\mathrm{kDa}$, whereas MPT-64 antigen was reported to have a molecular weight varied between $22.3 \mathrm{kDa}-28 \mathrm{kDa}$. Thus, these antigens will be freely filtered by glomerolus, then excreted into the urine (Ganguly \& Sharma 2012). The urine examination materials have high levels of variability in protein concentrations influenced by, among others, hydration factors. Therefore, to avoid confounding factors on the results of the study concentration of urine is carried out (Thomas et al 2010).

The majority of 22 positive urine samples were pulmonary TB and the rest were extrapulmonary TB receiving ATD (Anti Tuberculosis Drugs) for less than 1 month. Whereas, the 10 negative urine samples were from pediatric extra-pulmonary TB patients who had received ATD for more than 1 month. In extra-pulmonary TB patients there was a paucibacillary condition that was less than the number of bacteria in lung tuberculosis. Thus, the Mtb, which excites antigen ESAT-6, CFP-10, and MPT-64 in those patients was less than that in pulmonary TB patients (Noussair et al 2010).

In this study, healthy children who were subjected to the study were those between 3-14 years. Ministry of Health of the Republic of Indonesia in 2013 limited the age range of child TB between 0-14 years. Otherwise, a child is declared healthy because he meets the following requirements: never having any contact with adult TB, having normal chest X-ray, and negative TST.

In this study, from 32 healthy urine samples, 25 were negative, which means that the urine did not contain ESAT-6, CFP-10, and MPT-64 antigens of Mtb, while the other 7 samples were positive, probably indicating latent TB. In latent tuberculosis, $\mathrm{T}$ cell reactivity to $\mathrm{Mtb}$ antigen may occur, since there is a living Mtb inside the body. Chest X-ray images are usually showing no abnormalities, Sputum smear-negative results show no clinical symptoms, but therapy is still required to prevent reactivation (Raviglione et al 2012, Flynn et al 2011).

In this study, differences in urine examination of TB patients with healthy children were analyzed using chi square Wilson-Brown data analysis. At $95 \%$ confidence level, there was a significant difference in the results of urine examination between tuberculosis patients and healthy children with $\mathrm{p}$ value of $0.0002(\mathrm{p}<0.05)$. The specificity was found as much as $78 \%$, which means that the ICT method with urine samples can be satisfactory used to distinguish Mtb and Mott antigens contained in the body of pediatric TB patients. The sensitivity was found to be of $68.8 \%$, showing that ICT method with urine samples of pediatric TB patients can be used reliably to support the diagnosis.

\section{CONCLUSION}

Examination of ESAT-6, CFP-10, and MPT-64 antigens of Mtb can be performed in urine of pediatric TB patients with immunochromatography to support the diagnosis. This examination uses urine samples because it is safer and easier to obtain from pediatric patients. In addition, the use of ICT methods is also cheaper and faster than other methods. This research can be developed using other quantitative methods, such as ELISA.

\section{REFERENCES}

Arora J, Kumar G, Verma AK, Bhalla M, Sarin R, Myneedu VP (2015). Utility of MPT64 antigen detection for rapid Confirmation of Mycobacterium tuberculosis Complex. J Glob Infect Dis 7, 66-69

Bekmuryazeva A, Sypabekova M, Kanayeva D (2013). Tuberculosis diagnosis using immunodominant, secreted antigens of Mycobacterium tuberculosis. Tuberculosis, 1-8

Flynn J, Chan J, Lin P (2011). Macrophage and control of granulomatous inflammation in tuberculosis. Mucosal Immunol 4, 271-8

Ganguly N, Sharma P (2012). Mycobacterium tuberculosis RD-1 secreted antigen as protective and risk factor for tuberculosis. Dalam buku undersstanding tuberculosis-Global experience and innovative approaches to the diagnosis rijeka. Croasia, Intech publisher

Gustiani N, Parwaati I, Tjandrawati A, Lismayanti L (2014). Validitas pemeriksaan complex spesific antigen Mycobacterium tuberculosis region of difference 1-3 metode rapid immunocromatographypada sputum penderita tuberculosis paru. Majalah Kedokteran 46

Kleinnijenhuis J, et al (2011). Innate immune recognition of Mycobacterium tuberculosis. Hindawi Publishing Corporation Clinical and Developmental Immunology 2011

Krishnan N, Robertson BD, Thwaites G (2010). The mechanisms and concequences of the extra-pulmonary disemination of Mycobacterium tuberculosis. Tuberculosis (edinb) 90, 361-6

Ministry of Health of Republic of Indonesia (2013). Petunjuk Teknis Manajemen TB anak, 2-79

Notoatmodjo (2012). Metodologi penelitian kesehatan, Edisi Revisi. Jakarta, Rineke Xipta, p 35-43

Noussair L, Bert FDR, Leflon-Guibout, Gayet N, Nicholas-Chanoine MH (2009). Early diagnosis of extrapulmonary tuberculosis by anew procedure com- 
bining broth culture and PCR. J of Clin Micro 47,1452-7

Raviglione M, O’Brien R (2012). Tuberculosis. In: LoMc Graw Hill; ngo D, Kasper D, Jameson J, Fauci A, Hauser S, Loscalzo J, editor. Harrisons Principles of Internal Medicine. New York, The McGraw Hill, p 1340-1359

Sari SR (2011). Nilai diagnostik antigen TB dengan Rapid Test Device (TbAg) untuk tuberkulosis paru. Unpublished thesis. Surabaya, Faculty of Medicine, Universitas Airlangga

Smith I (2003). Mycobacterium tuberculosis pathogenesis and molecular determinants of virulence. Clin Microbiol Rev 16, 463-96
Thomas CE, Sexton W, Benson K, et al (2010). Urine collection and processing for protein biomarker. American Association for Cancer Research 19, 953-9

Tuuminen $\mathrm{T}$ (2012). Urine as a specimen to diagnose infections in twenty first century: focus on analytical accuracy. Immunology 3, 1-6

Wahyuningsih E (2014). Pola klinik tuberkulosis paru di RSUP Dr. Kariadi, Semarang Periode Juli 2012Agustus 2013. Jurnal Media Medika Muda 3, 1-19

Yusa, Maniam MBS (2016). Aktif dan kreatif belajar biologi. Bandung, Grafindo media pratama, p 149-153 